\title{
Excitatory Actions of GABA after Neuronal Trauma
}

\author{
Anthony N. van den Pol, ${ }^{1,2}$ Karl Obrietan, ${ }^{2}$ and Gong Chen ${ }^{1}$ \\ 1 Section of Neurosurgery, Yale University School of Medicine, New Haven, Connecticut 06520, and 2Department of \\ Biological Sciences, Stanford University, Stanford, California 94305
}

\begin{abstract}
GABA is the dominant inhibitory neurotransmitter in the CNS. By opening $\mathrm{Cl}^{-}$channels, GABA generally hyperpolarizes the membrane potential, decreases neuronal activity, and reduces intracellular $\mathrm{Ca}^{2+}$ of mature neurons. In the present experiment, we show that after neuronal trauma, GABA, both synaptically released and exogenously applied, exerted a novel and opposite effect, depolarizing neurons and increasing intracellular $\mathrm{Ca}^{2+}$. Different types of trauma that were effective included neurite transection, replating, osmotic imbalance, and excess heat. The depolarizing actions of GABA after trauma increased $\mathrm{Ca}^{2+}$ levels up to fourfold in some neurons, occurred in more than half of the severely injured neurons, and was long lasting ( $>1$ week). The mechanism for the reversed action of GABA appears to be a depolarized $\mathrm{Cl}^{-}$reversal potential that results in outward rather than inward movement of
\end{abstract}

$\mathrm{Cl}^{-}$, as revealed by gramicidin-perforated whole-cell patch-clamp recording. The consequent depolarization and resultant activation of the nimodipine sensitive $\mathrm{L}$ - and conotoxin-sensitive $\mathrm{N}$-type voltage-activated $\mathrm{Ca}^{2+}$ channel allows extracellular $\mathrm{Ca}^{2+}$ to enter the neuron. The long-lasting capacity to raise $\mathrm{Ca}^{2+}$ may give GABA a greater role during recovery from trauma in modulating gene expression, and directing and enhancing outgrowth of regenerating neurites. On the negative side, by its depolarizing actions, GABA could increase neuronal damage by raising cytosolic $\mathrm{Ca}^{2+}$ levels in injured cells. Furthermore, the excitatory actions of GABA after neuronal injury may contribute to maladaptive signal transmission in affected GABAergic brain circuits.

Key words: calcium; chloride; injury; GABA; hypothalamus; glutamate; digital imaging
GABA plays a widespread role as the major inhibitory transmitter in the brain, particularly in the hypothalamus (Tappaz et al., 1982; van den Pol, 1985; Randle et al., 1986; Decavel and van den Pol, 1992; Kim and Dudek, 1992) where GABAergic axons account for half of all presynaptic boutons (Decavel and van den Pol, 1990). In mature neurons in vivo or in vitro, GABA plays an inhibitory role, reducing electrical activity and lowering intracellular $\mathrm{Ca}^{2+}(\mathrm{Ob}-$ rietan and van den Pol, 1995a,b; van den Pol et al., 1995).

Many different factors contribute to secondary consequences of neuronal trauma aside from the death of neurons at the time of injury. These secondary factors can lead to neuronal incapacitation or cell death or can contribute to faulty information processing. A central second messenger in this regard is cytosolic $\mathrm{Ca}^{2+}$; sustained increases in $\mathrm{Ca}^{2+}$ can lead to compromised cell health and even to cell death. $\mathrm{Ca}^{2+}$ also is critically involved in gene expression, as a second messenger in intracellular information processing, and plays an essential role in synaptic transmitter release. Neurite outgrowth, for instance during recovery after injury, is dependent on specific cytosolic $\mathrm{Ca}^{2+}$ levels (Mattson and Kater, 1989).

Neurons can be injured not only by direct physical damage to the cell body but also by damage to processes, by temperature rises as in high fevers, by alterations in osmotic pressure owing to ischemia or problems with blood flow and edema after head trauma, and by excitotoxic responses to high levels of glutamate released by injury. We used in vitro models to study altered

Received Jan. 31, 1996; revised April 2, 1996; accepted April 5, 1996.

This work was supported by National Institutes of Health Grants NS34887 and NS10174, the National Science Foundation, and the Air Force Office of Scientific Research. We thank V. Cao and Y. Yang for technical assistance, and A. Belousov and $\mathrm{J}$. Chisholm for suggestions regarding this manuscript.

Correspondence should be addressed to Anthony N. van den Pol, Section of Neurosurgery, Yale University School of Medicine, 333 Cedar Street, New Haven, CT 06520.

Copyright (C) 1996 Society for Neuroscience $0270-6474 / 96 / 164283-10 \$ 05.00 / 0$ responses of traumatized neurons to both exogenously applied and synaptically released GABA under conditions in which we could rigorously control factors that might complicate interpretation of responses to injury in vivo.

In the present study, we used digital imaging with Fura-2 to study unusual $\mathrm{Ca}^{2+}$ rises in response to GABA after neuronal injury. Gramicidin-perforated whole-cell recording also was used to test the hypothesis that the mechanism of GABA excitation was attributable to a depolarized $\mathrm{Cl}^{-}$reversal potential, resulting in $\mathrm{Cl}^{-}$exodus rather than entry at GABA receptor activation. Unlike conventional whole-cell recording, gramicidin perforations allow analysis of GABA responses dependent on $\mathrm{Cl}^{-}$channel opening without artifactually altering intracellular $\mathrm{Cl}^{-}$levels (Meyers and Haydon, 1972; Reichling et al., 1994; Ebihara et al., 1995).

\section{MATERIALS AND METHODS}

Fura-2 digital imaging. Cells were loaded with $5 \mu \mathrm{M}$ Fura-2 AM ester (Molecular Probes, Eugene, OR). $\mathrm{Ca}^{2+}$ calibration was done with $\mathrm{Ca}^{2+}$ standards (Molecular Probes) according to the procedure of Grynkiewicz et al. (1985). Cells were imaged using a $40 \times$ Olympus objective with high $340 / 380 \mathrm{~nm}$ light transmittance on a Nikon Diaphot 300 inverted microscope. Ratiometric excitation was provided by a $150 \mathrm{~W}$ xenon lamp filtered sequentially through 340 and $380 \mathrm{~nm}$ filters in a Sutter filter wheel driven by a Lambda- 10 microprocessor controlled by a Universal Imaging computer and software. Agonists and antagonists were perfused over cells in a $180 \mu \mathrm{l}$ microscope chamber with a standard buffer containing (in $\mathrm{mm}$ ): $\mathrm{NaCl} 137$, glucose $25, \mathrm{KCl} 5$, HEPES $10, \mathrm{MgCl}_{2} 1, \mathrm{CaCl}_{2} 3, \mathrm{pH}$ 7.4. Chemicals were from Sigma (St. Louis, MO) except nimodipine and conotoxin (Research Biochemicals, Natick, MA). Additional procedural details of our use of Fura- $\mathrm{Ca}^{2+}$ imaging can be found elsewhere (Obrietan and van den Pol, 1995a,b).

Whole-cell patch-clamp recording. All electrophysiology experiments used gramicidin-perforated whole-cell patch-clamp recording. The gramicidin-perforated channels are relatively impermeable to $\mathrm{Cl}^{-}$anions (Meyers and Haydon, 1972; Reichling et al., 1994; Ebihara et al., 1995), making gramicidin ideal for studying the reversal potential of GABA- 
evoked $\mathrm{Cl}^{-}$currents without interfering with the intracellular $\mathrm{Cl}^{-}$concentration. The recording chamber was perfused continuously at a rate of $2 \mathrm{ml} / \mathrm{min}$ with a bath solution containing (in $\mathrm{mM}$ ): $162.5 \mathrm{NaCl}, 2.5 \mathrm{KCl}, 2$ $\mathrm{CaCl}_{2}, 10$ glucose, 10 HEPES, $\mathrm{pH}$ 7.3. The pipette solution contained (in $\mathrm{mM}$ ): $\mathrm{KMeSO}_{4}$ 145, $\mathrm{MgCl}_{2}$ 1, EGTA 1.1, HEPES 10, pH 7.3. Gramicidin was used at concentration of $20-50 \mu \mathrm{g} / \mathrm{ml}$ in the pipette solution. GABA $(50 \mu \mathrm{M})$ was applied to the cell through a micropipette with a tip diameter of 2-3 $\mathrm{m}$ positioned $2-3 \mu \mathrm{m}$ away from the cell using a Narishige (Tokyo, Japan) microinjector. A flow pipe with an outer diameter of 380 $\mu \mathrm{m}$ was aimed at the recorded neuron and continuously perfused the cell with bath solution to quickly wash off the GABA. Data were acquired with an AxoClamp-2B amplifier interfaced to a Macintosh computer using AxoData software and analyzed by Axograph and Igor (Wavemetrics) software. The sampling rate was $5 \mathrm{KHz}$ and filtered at $1 \mathrm{KHz}$.

Immunocytochemistry. GABA antiserum was used with immunoperoxidase to stain GABAergic neurons in vitro after fixation with $3 \%$ glutaraldehyde and membrane permeabilization with $0.4 \%$ Triton X-100. After incubation in the primary antibody used at a dilution of 1:3000, biotinlabeled goat anti-rabbit secondary was used, and after washing, the avidin-biotin-peroxidase complex (Vector Laboratories, Burlingame, CA) was used. The peroxidase chromagen was revealed with diaminobenzidine and hydrogen peroxide. Antiserum specificity and more detailed immunochemical procedures were described previously (Decavel and van den Pol, 1990). Absorbtion with GABA conjugated to a protein different than used to make the antiserum blocked positive immunostaining.

Tissue culture. Embryonic day 18 (E18) rat hypothalami were disaggregated with papain and plated on a polylysine substrate (molecular weight, $540,000 \mathrm{Da}$ ) (Collaborative Research, Bedford, MA). Cells were kept at $37^{\circ} \mathrm{C}$ and $5 \% \mathrm{CO}_{2}$ in a Napco 5410 incubator in glutamate- and glutaminefree DMEM (Gibco, Gaithersburg, MD) supplemented with $10 \%$ fetal bovine serum, $10 \mu \mathrm{M} \mathrm{CNQX}$, and $100 \mu \mathrm{M} \mathrm{AP}-5$, and $1 \mu \mathrm{M}$ cytosine arabinoside to reduce glial proliferation, as described elsewhere (Obrietan and van den Pol, 1995a,b). Explants were cut from 400- $\mu \mathrm{m}$-thick slices of late embryonic rats. To increase long-term viability, explants were reduced to a diameter of $\sim 1$ to $1.5 \mathrm{~mm}$ and were held onto a glass substrate with polylysine and maintained at $37^{\circ} \mathrm{C}$ in $5 \% \mathrm{CO}_{2}$.

\section{RESULTS}

\section{GABA-mediated $\mathrm{Ca}^{2+}$ rise after trauma}

Hypothalamic neurons cultured 24-35 d were traumatized by scraping them off the substrate they were growing on and replating them (Figs. $1 A-C, 2 A-D$ ). Other types of injury also were studied (Fig. $2 E-I)$. The replating procedure caused the loss of many processes from most neurons. Neurons then were plated on glass coverslips and studied with Fura-2 digital imaging (Grynkiewicz et al., 1985). When these cells were treated with GABA $(10 \mu \mathrm{M})$, their intracellular $\mathrm{Ca}^{2+}$ levels were raised (Fig. $2 A$ ), sometimes by more than fourfold from $65 \mathrm{~nm}$ to $+300 \mathrm{~nm}(n=475)$. This effect was found $3 \mathrm{hr}$ after trauma and continued for up to 2 weeks (Fig. $2 C, D$ ). Based on neurons that responded to GABA, the greatest magnitude $\mathrm{Ca}^{2+}$ rise was found at the earliest post-trauma interval of $3 \mathrm{hr}$ (Fig. $2 \mathrm{C}$ ). In striking contrast, nontraumatized control neurons after $24 \mathrm{~d}(n=58)$ and $35 \mathrm{~d}(n=$ 98) in vitro showed no $\mathrm{Ca}^{2+}$ rise in response to GABA (Fig. $2 B$ ). To prevent the release of endogenous transmitters that might confound the results by producing secondary effects, TTX (tetrodotoxin) (1 $\mu \mathrm{M}$ ) was used in experiments where GABA-evoked responses were studied.

We compared the percent of neurons that responded to GABA with at least a $20 \mathrm{nM} \mathrm{Ca}^{2+}$ rise as a function of time allowed for recovery after replating injury (Fig. $2 D$ ). The greatest number $(63 \%)$ of responding neurons was found $2 \mathrm{~d}$ after trauma, increasing from $3 \mathrm{hr}$ after trauma (38\%). By $14 \mathrm{~d}$ after injury, GABA continued to elicit a $\mathrm{Ca}^{2+}$ rise in $9 \%$ of the neurons.

To test the hypothesis that the role of GABA is reversed after several other different models of trauma, we compared the effect of raising the temperature to $41^{\circ} \mathrm{C}$, similar to the increase in temperature found in a high fever (Fig. $2 E$ ), raising or lowering
(Fig. $2 F$ ) the osmotic pressure as occurs after head trauma, transecting neurites with a sharp pipette, and stimulation with 100 $\mu \mathrm{M}$ glutamate (excitotoxic model). Compared with controls (Fig. $2 G-I)$, neurons $(n=890)$ in four of these trauma models showed that GABA raised cytosolic $\mathrm{Ca}^{2+}$ (Fig. $\left.2 H, I\right)(p<0.05 ; t$ test). The effect of osmotic trauma in reversing GABA actions was rapid. Whereas before trauma, little evidence of GABA-mediated $\mathrm{Ca}^{2+}$ rises was found, the same cells showed GABA-elicited $\mathrm{Ca}^{2+}$ rises minutes after hypotonic treatment. Interestingly, in $30 \%$ of the neurons $(n=124)$ that showed a GABA-induced $\mathrm{Ca}^{2+}$ rise, the response to $10 \mu \mathrm{M}$ GABA was substantially greater than the response to $100 \mu \mathrm{M}$ NMDA (Fig. $2 E$ ). In some neurons, the intracellular $\mathrm{Ca}^{2+}$ level was raised to over $600 \mathrm{~nm}$ by GABA, a level that could be toxic if maintained.

We also used explants of brain tissue to ensure that the actions of GABA on traumatized tissue were not restricted to a dispersed culture paradigm. Small nondispersed explants of brain tissue from the hypothalamus were studied after $16 \mathrm{~d}$ in vitro. Neurons were identified by their response to $30 \mu \mathrm{M}$ NMDA. Whereas no neurons $(n=64)$ in control explants showed $\mathrm{Ca}^{2+}$ responses to GABA after hypotonic insult (220 mOsm; $5 \mathrm{~min}$ ) (Fig. 3B), 43\% of 108 neurons in traumatized explants showed a $\mathrm{Ca}^{2+}$ rise in response to GABA, as shown by the typical response in Figure $3 A$. To determine whether neurons from other brain regions would show the unusual actions of GABA after trauma, we also used cortical explants. With the exception of one cell, control neurons showed no $\mathrm{Ca}^{2+}$ response to GABA $(n=39)$ (Fig. $\left.3 D\right)$. In contrast, after trauma, the number of cortical neurons responding to GABA showed a large increase, and $23 \%$ of 88 neurons showed a $\mathrm{Ca}^{2+}$ rise (Fig. $3 C$ ).

The two primary GABA receptors are the ionotropic $\mathrm{GABA}_{\mathrm{A}}$ receptor that opens $\mathrm{Cl}^{-}$channels and the G-protein-coupled $\mathrm{GABA}_{\mathrm{B}}$ receptor. The $\mathrm{GABA}_{\mathrm{A}}$ antagonist bicuculline $(20 \mu \mathrm{M})$ blocked the $\mathrm{Ca}^{2+}$ elevating actions of GABA (Fig. 4A-C). Muscimol $(10 \mu \mathrm{M})$, a specific $\mathrm{GABA}_{\mathrm{A}}$ agonist, evoked $\mathrm{Ca}^{2+}$ rises similar to those evoked by GABA in traumatized neurons (Fig. $4 B$ ) but not in age-matched control neurons. On the other hand, baclofen $(10 \mu \mathrm{M})$, a GABA $\mathrm{B}$ agonist, showed no effect on traumatized neurons (Fig. $4 B$ ). These data suggest that the $\mathrm{Ca}^{2+}$ rise is dependent on the $\mathrm{GABA}_{\mathrm{A}} \mathrm{Cl}^{-}$channel.

To determine whether the mechanism by which GABA raises intracellular $\mathrm{Ca}^{2+}$ might be through voltage-activated $\mathrm{Ca}^{2+}$ channels, we tried to block the GABA- mediated $\mathrm{Ca}^{2+}$ rise with nimodipine, an L-type channel blocker, and $\omega$-conotoxin-GVIA, an N-type channel blocker. Whereas conotoxin $(1 \mu \mathrm{M})$ depressed the $\mathrm{Ca}^{2+}$ rise slightly (12\% decrease; $n=25$ ) (Fig. $4 E$ ), nimodipine $(1 \mu \mathrm{M})$ caused a substantial reduction in the muscimol-induced $\mathrm{Ca}^{2+}$ rise, blocking $64 \%(n=21)$ of the $\mathrm{Ca}^{2+}$ increase (Fig. $\left.4 D\right)$. If the effects of conotoxin and nimodipine are combined, they blocked $76 \%$ of the GABA-induced $\mathrm{Ca}^{2+}$ rise. As both conotoxin and dihydropyridines such as nimodipine block $\mathrm{Ca}^{2+}$ entry induced by depolarizing agents (Nowicky et al., 1985; Thayer et al., 1986; McCarthy and Tan Piengco, 1992; Reuter, 1995), these data suggest that GABA generates the $\mathrm{Ca}^{2+}$ rise in traumatized neurons by depolarizing the neuron and that the $\mathrm{Ca}^{2+}$ entry would be secondary to the depolarization, mostly through the L-type voltage-activated $\mathrm{Ca}^{2+}$ channel (Fig. $4 F$ ).

\section{Depolarizing action of GABA after trauma: perforated whole-cell recording}

To provide support for our hypothesis that the mechanism underlying the $\mathrm{Ca}^{2+}$ rise after trauma was related to GABA-induced 

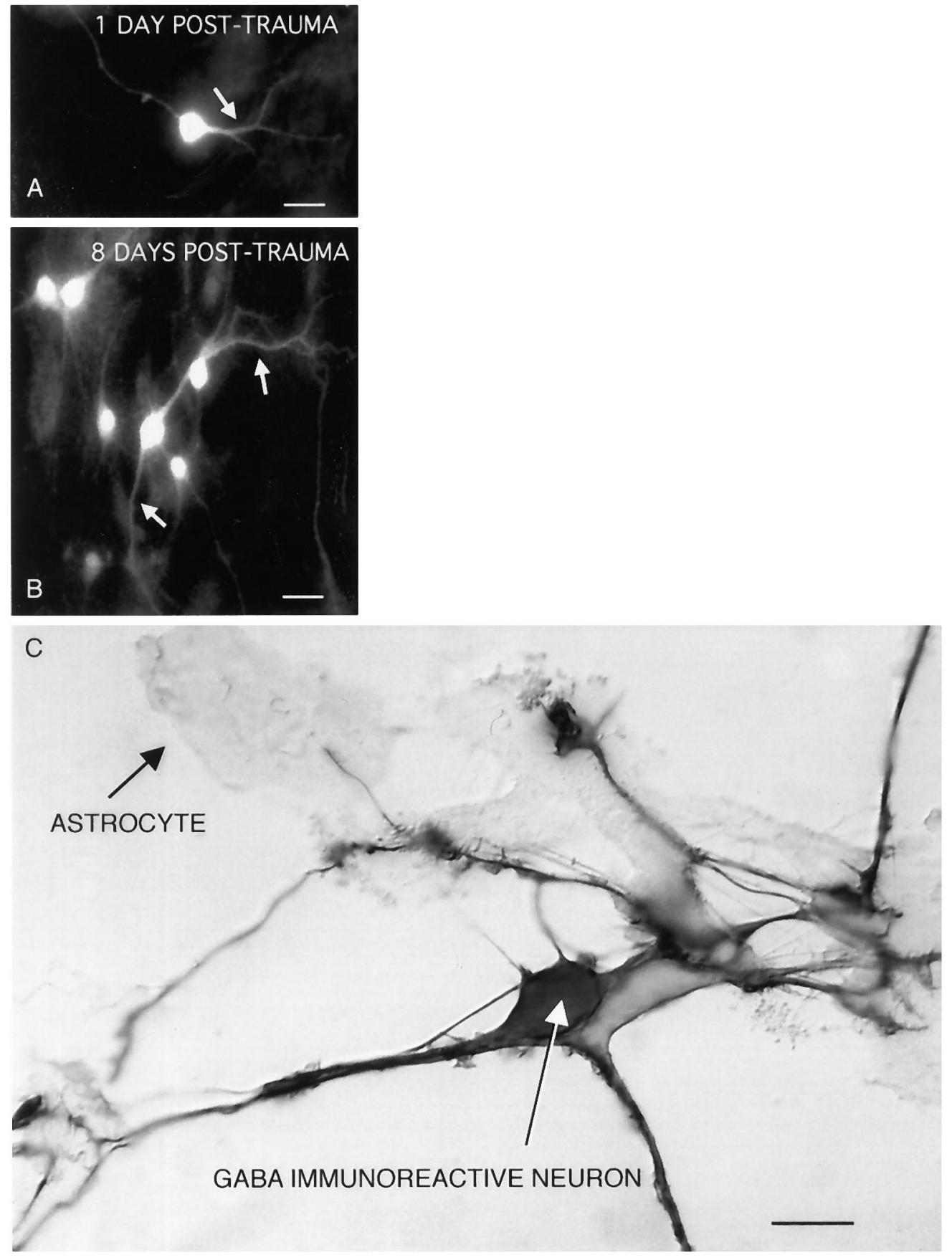

Figure 1. Morphology of dye-loaded neurons. Neurons were loaded with Fura-2 and imaged after injury. Photomicrographs show the $380 \mathrm{~nm}$ excitation image. Immediately after plating, neurons had few neuritic processes. $A$, One day after injury, all neurons had long processes (arrow). Scale bar, 15 $\mu \mathrm{M}$. $B$, Eight days after injury, neurons had extensive dendrites and elaborate axons (arrow). Scale bar, $15 \mu \mathrm{m}$. $C$, Peroxidase immunolabeling shows GABA-immunoreactive neuron (long arrow) in hypothalamic cultures. Underlying astrocytes (short arrow) were not immunoreactive. This micrograph was made with a differential interference contrast condenser $4 \mathrm{~d}$ after plating. Scale bar, $12 \mu \mathrm{m}$. depolarizations, we used gramicidin-perforated whole-cell recording to measure the intact $\mathrm{Cl}^{-}$reversal potential, which generally is distorted by conventional whole-cell recording. Neurons that were traumatized by replating after $4 \pm 1$ weeks in vitro and recording $2 \mathrm{~d}$ later showed a significantly $(p<0.01 ; t$ test $)$ reduced bicuculline-sensitive $\mathrm{Cl}^{-}$reversal potential $\left(E_{\mathrm{GABA}}=-45 \pm 4\right.$ (SEM) $\mathrm{mV} ; n=10$ ) compared with nontraumatized controls of similar ages $\left(E_{\mathrm{GABA}}=-70 \pm 2 \mathrm{mV} ; n=10\right)$ (Fig. $\left.5 D, E\right)$. At a membrane potential of $-60 \mathrm{mV}$, a brief application of GABA evoked a mean depolarization of $12 \pm 3 \mathrm{mV}$ in traumatized neurons (Fig. $5 C$ ), but in striking contrast evoked a hyperpolarization of $-10 \pm 2 \mathrm{mV}$ in age-matched controls (Fig. 5A). Furthermore, in some traumatized cells, GABA depolarized cells to the threshold for evoking action potentials, leading to an increase in electrical activity (Fig. 5C). A depolarizing effect of GABA was not found in control neurons. We also examined the resting membrane potential of control and traumatized neurons. Control neurons had a mean resting potential of $-55 \pm 3$ (SEM) $\mathrm{mV}$ compared with $-43 \pm 5 \mathrm{mV}$ in injured neurons $(n=20)$. The mean input resistance was $1.0 \pm 0.2 \mathrm{G} \Omega$ in control cells compared with $1.4 \pm 0.2 \mathrm{G} \Omega$ in injured neurons.

The importance of using perforated-patch recording was illustrated dramatically by experiments in which we broke through the perforated membrane to achieve conventional whole-cell recordings and were unable to detect a difference in the $\mathrm{Cl}^{-}$reversal potential between control and traumatized neurons (both $-98 \pm$ $2 \mathrm{mV}$ ). In some cells in which GABA elicited a depolarizing action at a holding potential of $-60 \mathrm{mV}$, we broke through the 


\section{GABA INCREASES $\mathrm{Ca}^{2+}$ IN TRAUMATIZED NEURONS}

A. TRAUMATIZED NEURON: 1 DAY POST TRAUMA

35 DIV

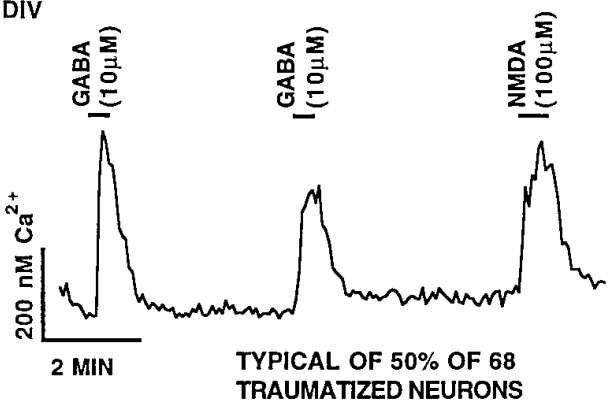

B. NON-TRAUMATIZED CONTROL NEURON

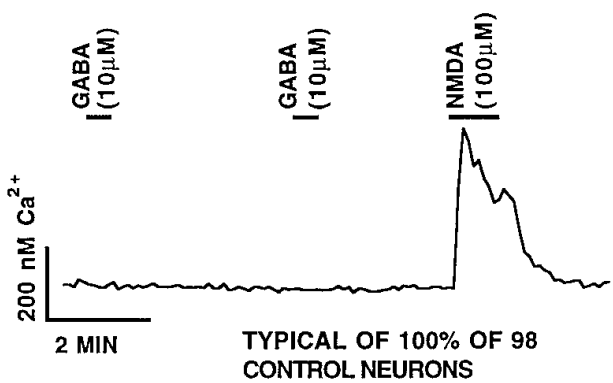

C. TIME-COURSE OF GABA-INDUCED $\mathrm{Ca}^{2}+$ INCREASE

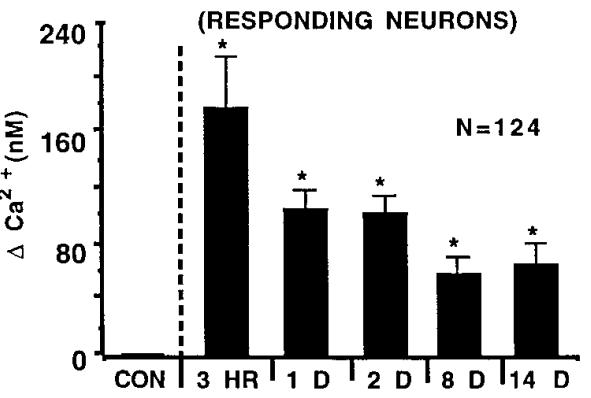

D. NEURONS WITH A GABA-EVOKED $\mathrm{Ca}^{2}+$ RISE

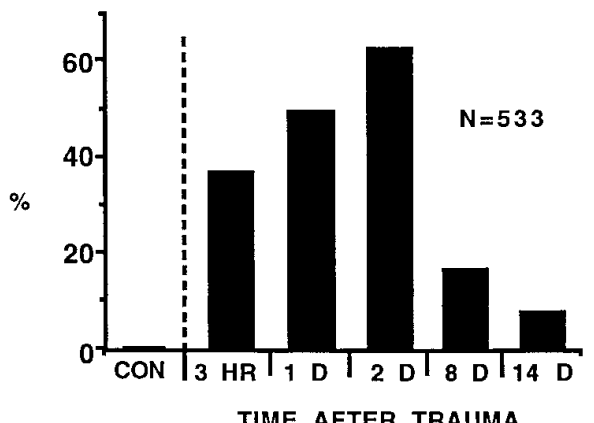

DIFFERENT FORMS OF TRAUMA UNDERLIE GABA-INDUCED Ca ${ }^{2+}$ RISE

E. HIGH TEMPERATURE

40 DIV

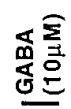

吕高
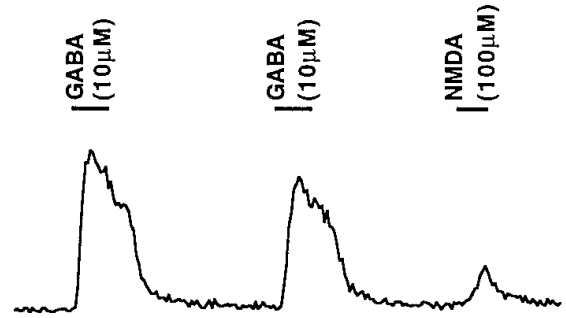

F. HYPOTONIC BUFFER

G. CONTROL
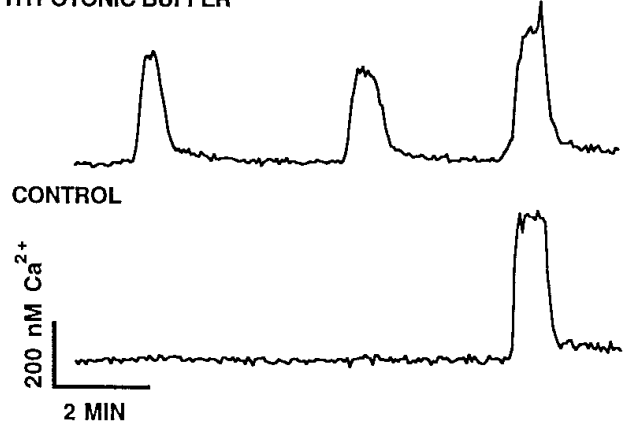

H. RELATIVE Ca ${ }^{2}+$ RESPONSE to GABA

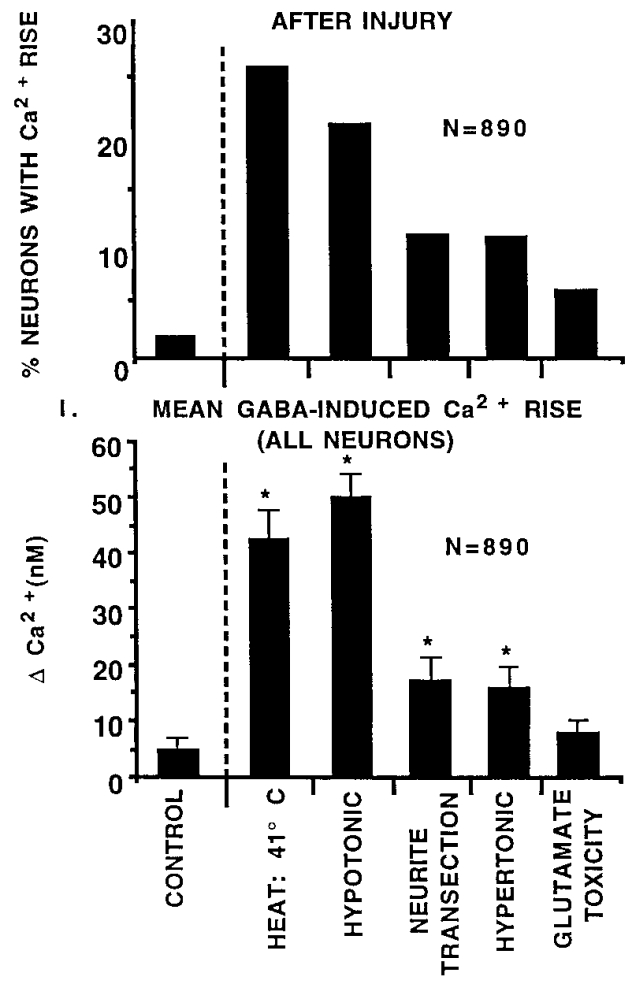

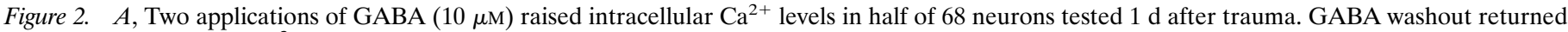

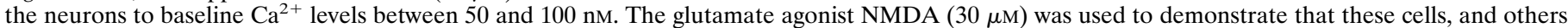

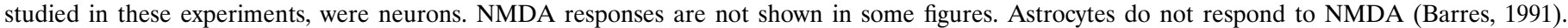

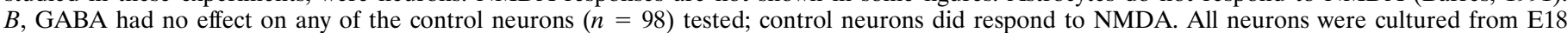




\section{GABA EVOKED $\mathrm{Ca}^{2+}$ RISES IN TRAUMATIZED EXPLANTS}

\section{A. HYPOTHALAMUS/TRAUMA}

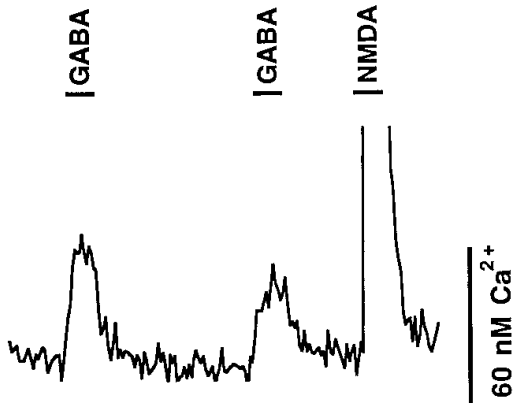

\section{B. HYPOTHALAMUS/CONTROL}

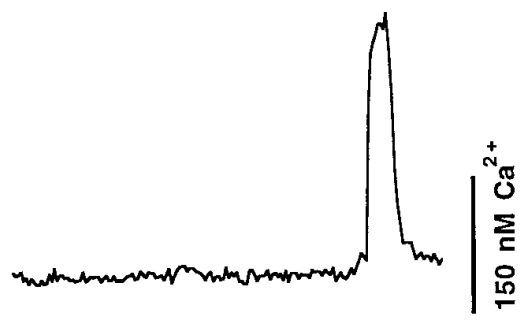

\section{CORTEX/TRAUMA}

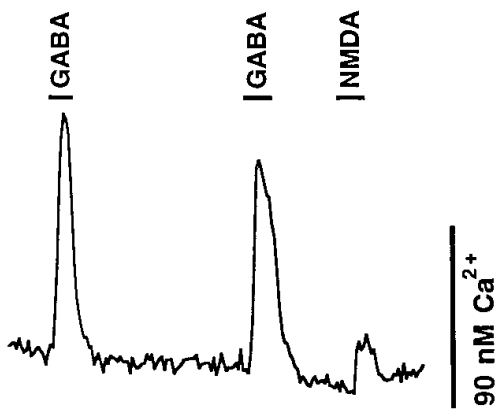

D. CORTEXICONTROL

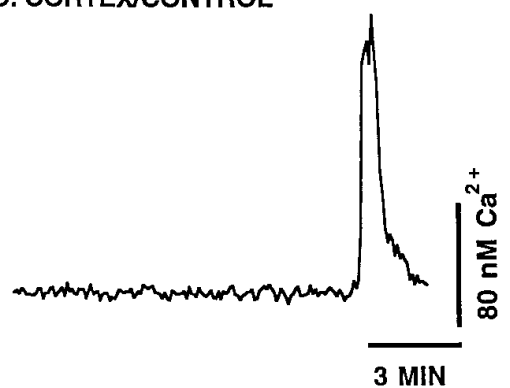

Figure 3. Actions of GABA in traumatized explants. $A$, After 5 min of hypotonic buffer trauma, followed by $10 \mathrm{~min}$ of normal buffer, GABA $(10 \mu \mathrm{M})$ applied to hypothalamic explants caused $\mathrm{Ca}^{2+}$ rises, as shown in this example in which a neuron responded to two applications of GABA and then to NMDA $(30 \mu \mathrm{M})$. $B$, Typical nontraumatized control neuron showed no response to GABA but did respond to NMDA. $C$, This cortical neuron showed $\mathrm{Ca}^{2+}$ rises in response to two applications of GABA $(10 \mu \mathrm{M})$ and a smaller response to NMDA $(30 \mu \mathrm{M})$. $D$, Almost all control cortical neurons showed no response to GABA but did respond to NMDA. perforated patch to obtain conventional whole-cell access. In these cells, if the recording pipette contained a low concentration of $\mathrm{Cl}^{-}$, GABA actions were hyperpolarizing, and if the pipette contained high $\mathrm{Cl}^{-}$levels, GABA was consistently depolarizing. These data demonstrate the importance of gramicidin use to avoid artifactual resetting of $E_{\mathrm{Cl}^{-}}$by pipette $\mathrm{Cl}^{-}$diffusion.

\section{Response to synaptically released GABA after trauma}

Our cultures contained a large number (about 30\%) of neurons that were immunoreactive for GABA (Fig. $1 C$ ). To test whether GABA released by these neurons also could initiate $\mathrm{Ca}^{2+}$ rises, we examined 4-week-old cultures $4 \mathrm{~d}$ after trauma. A high level of $\mathrm{Ca}^{2+}$ activity was found (Fig. 6A, arrow) even in the presence of glutamate receptor antagonists (D,L-2-amino-5-phosphonovalerate [AP-5 $(100 \mu \mathrm{M})$ ] and 6-cyano-7-nitroquinoxaline, [CNQX $(10 \mu \mathrm{M})])$ used to block the actions of glutamate released from hypothalamic neurons (van den Pol and Trombley, 1993). Bicuculline $(20 \mu \mathrm{M})$ blocked this $\mathrm{Ca}^{2+}$ activity (Fig. $6 A$ ), supporting the argument that GABA released from presynaptic axons generated complex $\mathrm{Ca}^{2+}$ rises. This high activity was not found in age-matched control neurons (Fig. 6B). Only rare control neurons ( $2 \%$ of 300 ) showed a $\mathrm{Ca}^{2+}$ depression in response to bicuculline. In contrast, after injury, bicuculline caused a depression of $\mathrm{Ca}^{2+}$ levels in $15 \%$ of the injured cells $(n=123)$, suggesting that GABA released by presynaptic axons raised the baseline $\mathrm{Ca}^{2+}$ levels of traumatized, but not control, neurons. These data support the conclusion that the $\mathrm{Ca}^{2+}$ rise is not simply an artifact of unusual concentrations of GABA applied to the entire membrane surface but can be generated at the synaptic level by axonal release of GABA.

hypothalami and were maintained in vitro for $35 \mathrm{~d}$. $C$, The mean GABA-evoked $\mathrm{Ca}^{2+}$ rise at intervals from $3 \mathrm{hr}$ to $14 \mathrm{~d}(D)$ after trauma was measured. The largest mean rise in this experiment $(+180 \mathrm{~nm})$ was found $3 \mathrm{hr}$ after trauma. This initial large response may in part be attributable to $\mathrm{Cl}^{-}$that leaked into the neuron at the point of injury; this would tend to lower the GABA reversal potential and thereby generate a large GABA-induced depolarization. Over time, the magnitude of the $\mathrm{Ca}^{2+}$ response decreased to $+68 \mathrm{~nm}$ at $14 \mathrm{~d}$ after trauma. Only cells that responded to GABA were included in this analysis. $D$, The greatest number of neurons $(63 \%)$ that responded to GABA with a $\mathrm{Ca}^{2+}$ rise was found $2 \mathrm{~d}$ after trauma. The mean response in $C$ and the percent of responders were based on cells that also responded to NMDA $(30 \mu \mathrm{M})$. Some cells that did not respond to NMDA did respond to GABA with a $\mathrm{Ca}^{2+}$ rise. All experiments $(A-H)$ in this series were performed in the presence of $1 \mu \mathrm{M}$ TTX to block release of endogenous transmitters. Baseline $\mathrm{Ca}^{2+}$ levels were between 40 and $100 \mathrm{~nm}$; there was no difference in baseline $\mathrm{Ca}^{2+}$ between controls and neurons traumatized at least $3 \mathrm{hr}$ previously. $E$, After elevating the temperature to $41^{\circ} \mathrm{C}$ for $5 \mathrm{~min}$, GABA generated $\mathrm{Ca}^{2+}$ rises. $\mathrm{Ca}^{2+}$ rises elicited by $10 \mu \mathrm{M}$ GABA sometimes were greater than the response to higher concentrations of NMDA $(100 \mu \mathrm{M}) . F$, This cell is typical of cells showing a $\mathrm{Ca}^{2+}$ rise in response to GABA after lowering the buffer osmolarity by $30 \%$ to $220 \mathrm{mOsm}$ for $5 \mathrm{~min}$ and testing immediately thereafter. $G$, This example is typical of control cells after $40 \mathrm{~d}$ in vitro. A small number $(2 \%)$ showed $\mathrm{Ca}^{2+}$ rises in response to GABA. These types of cells were not found in 3- to 4-week-old cultures. This $2 \%$ may have been composed of unhealthy cells, sometimes found in old cultures (Obrietan and van den Pol, 1995b). H, Percent of all 890 cells that showed Ca ${ }^{2+}$ rises in response to 10 $\mu$ M GABA. I, Mean $\mathrm{Ca}^{2+}$ rise evoked by GABA in all cells tested (responders and nonresponders). Stars over SEM bars indicate groups statistically different from controls. 


\section{A. BICUCULLINE BLOCK OF GABA- EVOKED $\mathrm{Ca}^{2+}$ INCREASE}
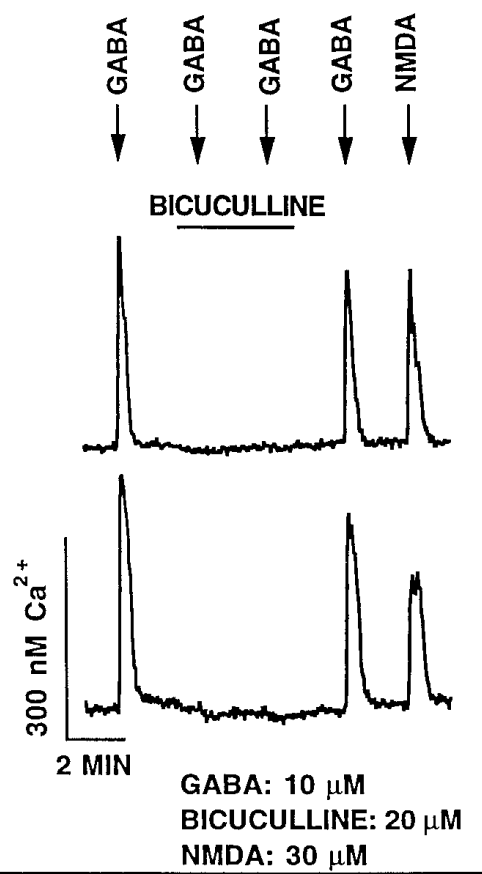

D. NIMODIPINE REDUCES $\mathrm{Ca}^{2+}$ RISE
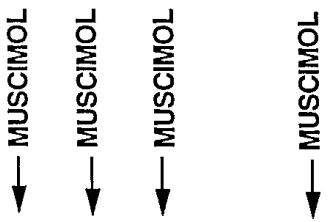

NIMODIPINE

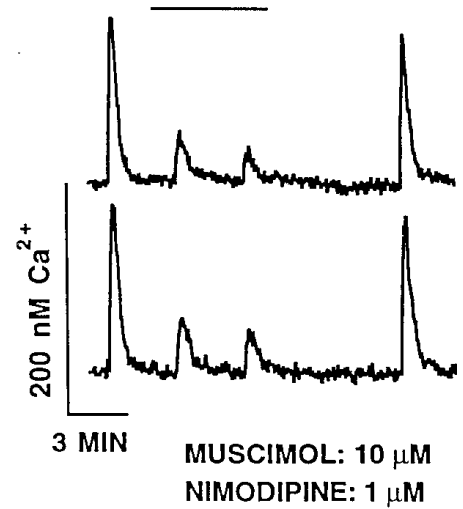

B. GABA $A$ RECEPTOR ACTIVATION EVOKES $\mathrm{Ca}^{2+}$ INCREASE
C. RELATIVe $\mathrm{Ca}^{2}+$ RISE
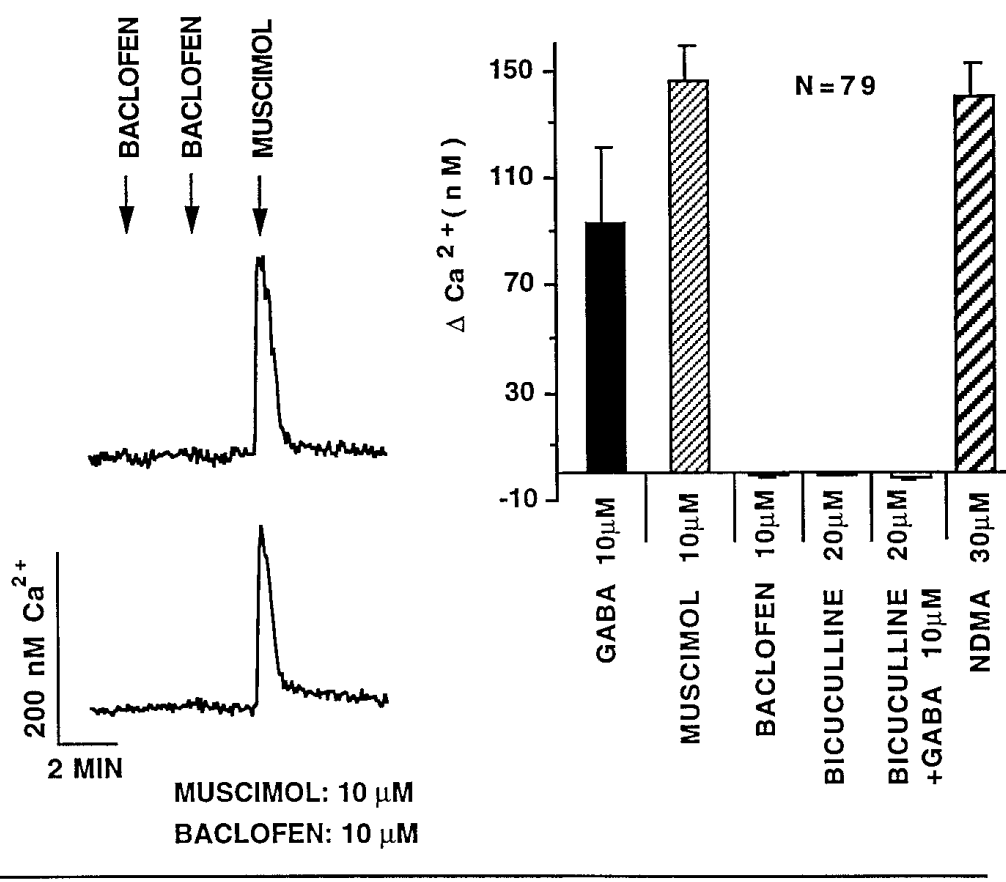

MUSCIMOL: $10 \mu \mathrm{M}$

BACLOFEN: $10 \mu \mathrm{M}$

E. CONOTOXIN AND Ca ${ }^{2+}$ RISE

F. VOLTAGE ACTIVATED $\mathrm{Ca}^{2}+$ CHANNELS
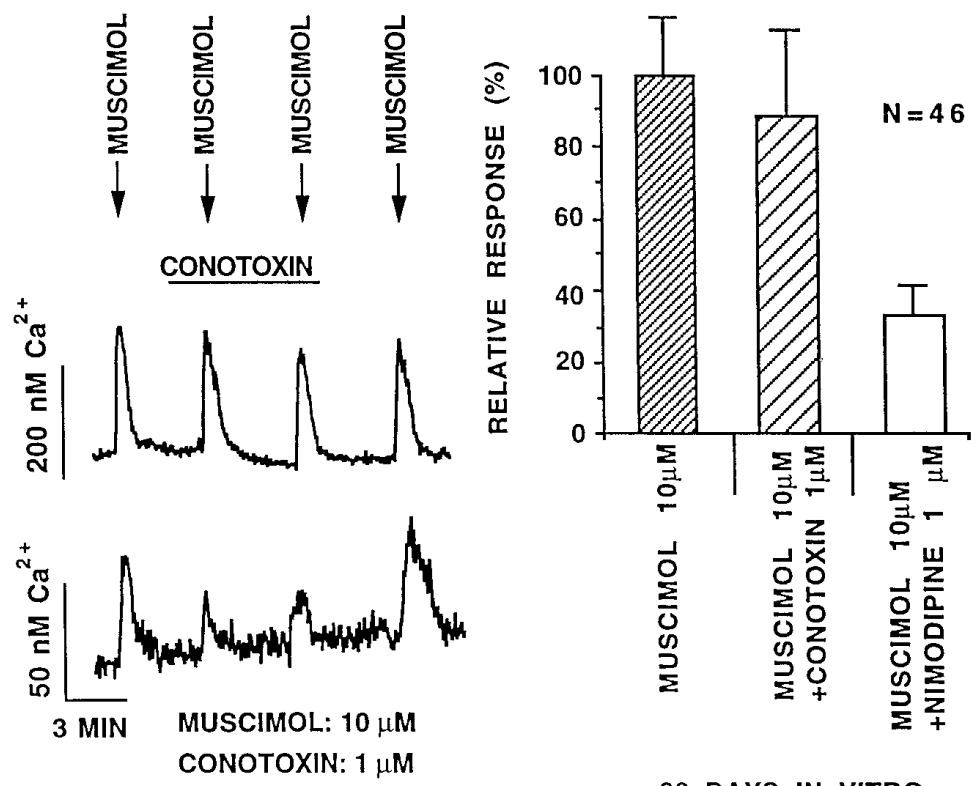

28 DAYS IN VITRO
4 DAYS POST TRAUMA

Figure 4. Mechanisms of action. GABA responses $2 \mathrm{~d}$ after replating trauma in 4-week-old cultures. $A$, GABA $(10 \mu \mathrm{M})$ elicited Ca ${ }^{2+}$ rises that were blocked with bicuculline $(20 \mu \mathrm{M})$ in these two representative neurons. NMDA $(30 \mu \mathrm{M})$ generated a $\mathrm{Ca}^{2+}$ rise of similar magnitude. $B$, The GABA $\mathrm{B}_{\mathrm{B}}$ agonist baclofen $(10 \mu \mathrm{M})$ did not elicit a $\mathrm{Ca}^{2+}$ rise, but in the same two neurons, the $\mathrm{GABA}_{\mathrm{A}}$ agonist muscimol $(10 \mu \mathrm{M})$ did elicit a Ca ${ }^{2+}$ rise. $C$, The relative $\mathrm{Ca}^{2+}$ rise in 79 neurons was compared for the different agonists and antagonists shown in $A$ and $B$. Bars show mean \pm SEM. $D$, The muscimol generated $\mathrm{Ca}^{2+}$ rise was reduced substantially by the dihydropyridine nimodipine $(1 \mu \mathrm{M}) . E$, $\omega$-Conotoxin $(1 \mu \mathrm{M})$ had a small effect on the muscimol elicited Ca ${ }^{2+}$ rise. The maximal effect of conotoxin in single neurons was a $38 \%$ depression of $\mathrm{Ca}^{2+}$ rises. $F$, This bar graph shows the mean relative $\mathrm{Ca}^{2+}$ change with the response to muscimol set at $100 \%$. Whereas the $\mathrm{N}$-type channel blocker conotoxin showed a small effect ( $-12 \%)$, the L-channel antagonist nimodipine blocked $64 \%$ of the GABA-evoked $\mathrm{Ca}^{2+}$ rise, with a maximum block of $88 \%$ in some neurons. TTX $(1 \mu \mathrm{M})$ was included in the buffer in these experiments to block action potential-dependent release of other transmitters. 


\section{DEPOLARIZING EFFECT OF GABA AFTER TRAUMA}

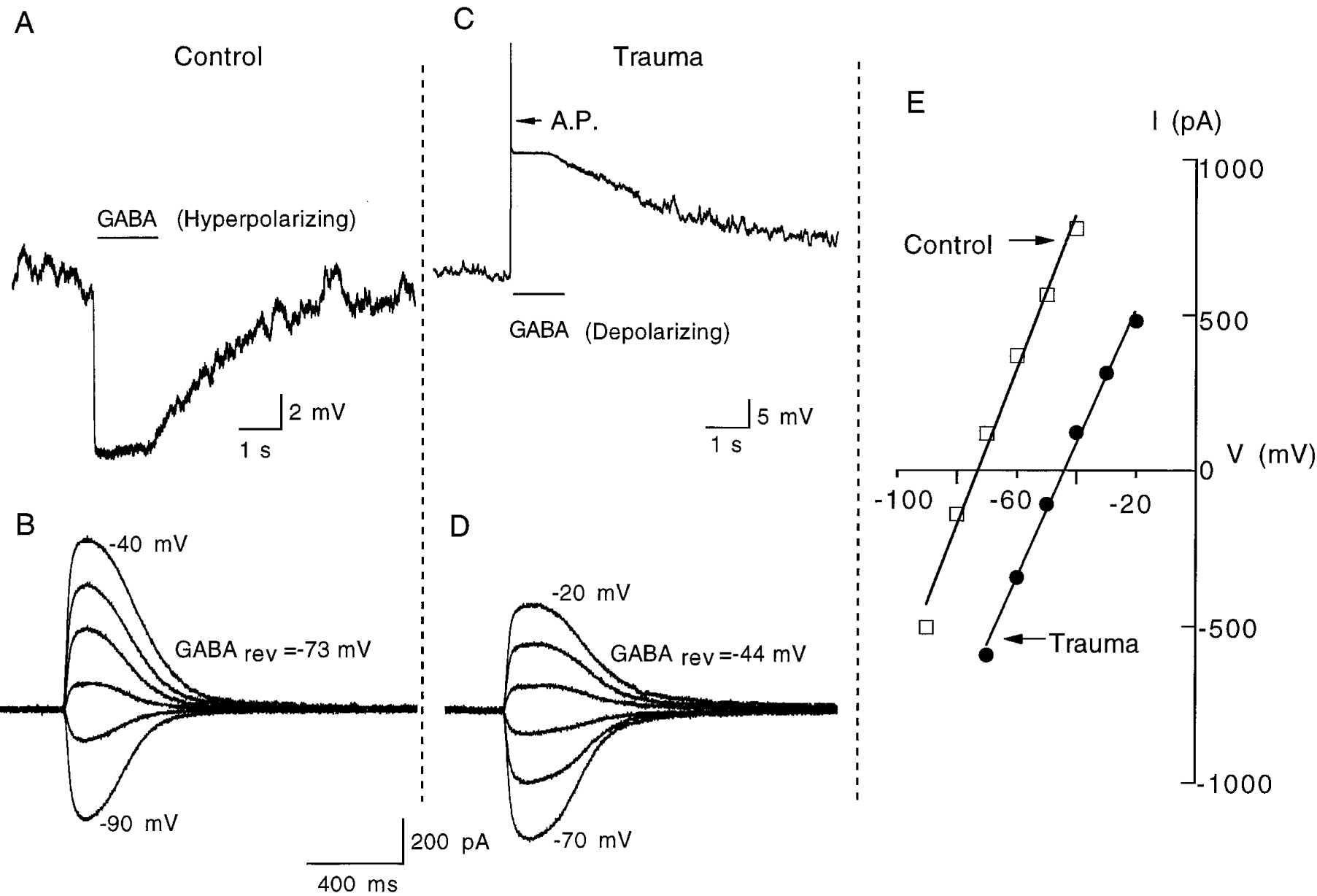

Figure 5. GABA depolarizes neurons after trauma. $A, B$, Control neurons. $C, D$, Traumatized neurons. $A$, GABA induced a hyperpolarization from -60 $\mathrm{mV}$ to $-72 \mathrm{mV}$ in a typical control neuron cultured for $33 \mathrm{~d}$. $C$, GABA depolarized the neuronal membrane potential from $-60 \mathrm{mV}$ to $-38 \mathrm{mV}$, generating an action potential (A.P.) in a representative traumatized neuron ( $2 \mathrm{~d}$ after replating 33 -d-old cultured neurons). $B, D$, The reversal potential of GABA-evoked currents determined by gramicidin-perforated patch-clamp recording shifted positively after trauma. The holding potential was -60 $\mathrm{mV}$. The command potential was increased by $10 \mathrm{mV}$ steps, and then GABA was applied briefly to determine its reversal potential. Note that GABA evoked outward currents between -70 and $-50 \mathrm{mV}$ in the control neuron, but inward currents in the traumatized neuron. $E, I-V$ curve of the GABA-evoked currents in $C$ and $D$.

\section{Nonadditive effects of GABA and glutamate}

In addition to the immediate effect of trauma on neurons, secondary injury also may result in neuronal death, in part owing to high levels of intracellular $\mathrm{Ca}^{2+}$ arising from excessive release of the excitatory transmitter glutamate (Olney and Sharpe, 1969; Choi, 1988). Because both GABA and glutamate could raise intracellular $\mathrm{Ca}^{2+}$ after injury, we compared the effects of the two amino acid transmitters. In many cells, glutamate raised $\mathrm{Ca}^{2+}$, but in some injured cells (second cell, Fig. $6 C$ ), GABA evoked a greater rise. The combined application of glutamate $(5 \mu \mathrm{M})$ and GABA $(5 \mu \mathrm{M})$ was not additive but instead resulted in a $\mathrm{Ca}^{2+}$ rise that was intermediate between the rise elicited by GABA and glutamate, irrespective of which amino acid caused a higher $\mathrm{Ca}^{2+}$ rise (Fig. 6C,D). That the third (combined) response was not attributable simply to a desensitized glutamate response, run down was determined by comparing two glutamate applications. In those cases in which the time between applications was similar to that used to examine the combined effects of glutamate and GABA, each of the two responses was similar (van den Pol et al., 1995).

\section{DISCUSSION}

Neurons express functional GABA receptors very early in development (Fiszman et al., 1990; Walton et al., 1993; Chen et al., 1995). Some embryonic, but not mature, neurons show $\mathrm{Ca}^{2+}$ rises in response to GABA (Reichling et al., 1994; Ben-Ari et al., 1989; Yuste and Katz, 1991; Obrietan and van den Pol, 1995a). Embryonic neurons both in culture and in brain slices can be depolarized by GABA (Obata et al., 1978; Connor et al., 1987; Ben-Ari et al., 1989; Cherubini et al., 1991; Chen et al., 1996), leading to the possibility that GABA can play an excitatory role in early development (Cherubini et al., 1991). The depolarizing activity of GABA in the present study in traumatized neurons is caused by a depolarized $\mathrm{Cl}^{-}$reversal potential, a condition that results in $\mathrm{Cl}^{-}$ exit rather than entry when GABA-gated channels are open. What is striking about the present results is that they indicate a very rapid (minutes) reversal of the role of GABA. That this result is not simply attributable to injury-induced $\mathrm{Cl}^{-}$entry into the cell, thereby depolarizing the $\mathrm{Cl}^{-}$reversal potential, is suggested by the extended time period ( 2 weeks) during which GABA can exert 


\section{ENDOGENOUS GABA RELEASE RAISES $\mathrm{Ca}^{2+}$}

A. 4 DAYS POST-TRAUMA

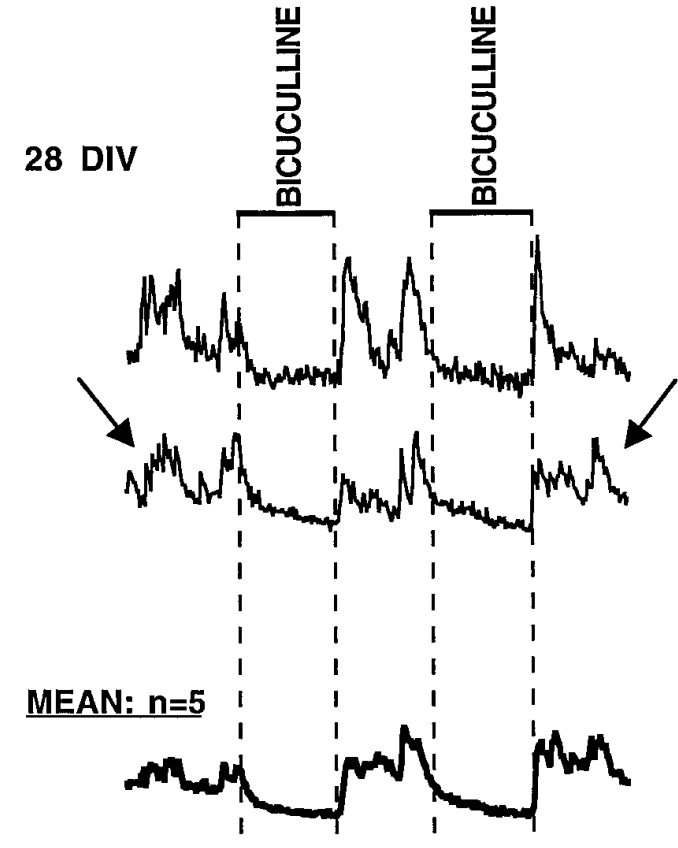

BICUCULLINE: $20 \mu \mathrm{M}$
B. CONTROL

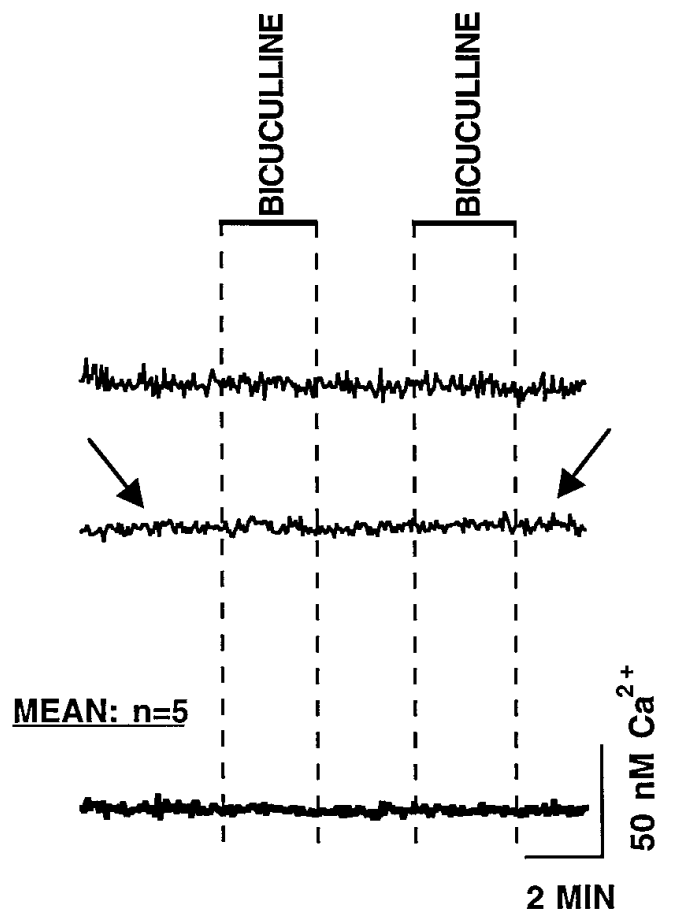

\section{RESPONSE TO GABA AND GLUTAMATE}

C.

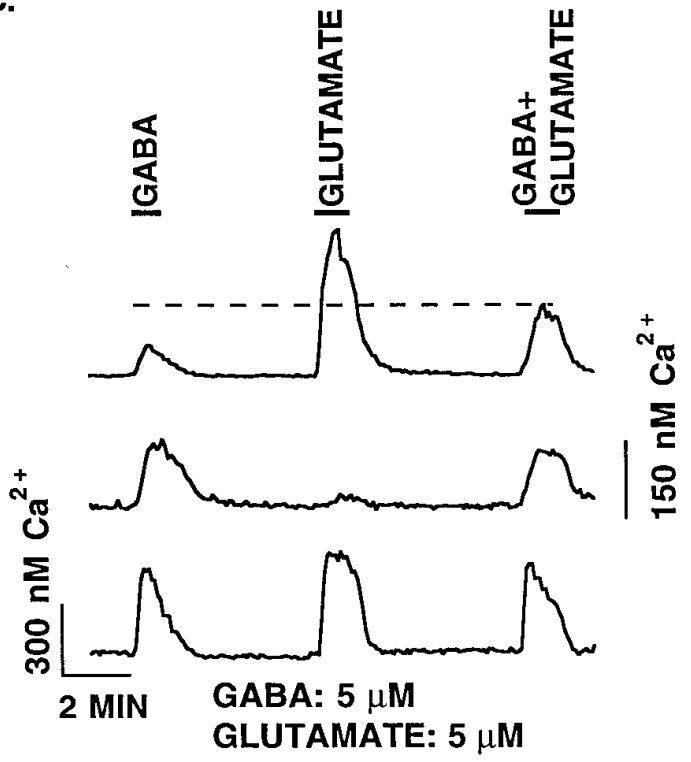

D.

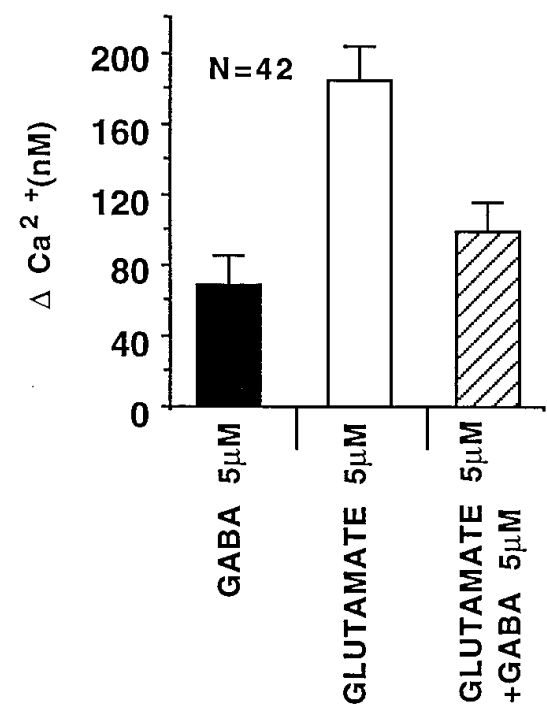

Figure 6. A, Only in injured neurons ( $4 \mathrm{~d}$ after trauma) was a high level of $\mathrm{Ca}^{2+}$ transients seen (arrow) in the presence of glutamate receptor blockers

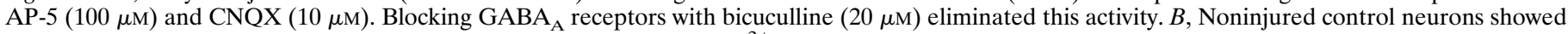
little spontaneous activity (arrow), and bicuculline had little effect on $\mathrm{Ca}^{2+}$ levels. $C$, In the presence of TTX (1 $\left.\mu \mathrm{M}\right)$, traumatized neurons responded to GABA $(5 \mu \mathrm{M})$, glutamate $(5 \mu \mathrm{M})$, and the combined application of glutamate and GABA $(5 \mu \mathrm{M}$ each). Responses of the three neurons shown are typical of the responses elicited. The combined application of glutamate and GABA led to a $\mathrm{Ca}^{2+}$ rise of an intermediate amplitude (dotted line in top neuron) between the rises elicited by each of the amino acids tested separately. $D$, The mean responses \pm SEM to glutamate, GABA, and glutamate + GABA are depicted in this bar graph. 
a $\mathrm{Ca}^{2+}$-elevating role and by the increase in the percentage of neurons showing $\mathrm{Ca}^{2+}$ rises in response to GABA between $3 \mathrm{hr}$ and $2 \mathrm{~d}$ after trauma.

The strong, rapid response (minutes after trauma) may be attributable to $\mathrm{Cl}^{-}$entry into the cell at the time of injury and a retarded $\mathrm{Cl}^{-}$transporter or pump passing $\mathrm{Cl}^{-}$back out of the cell. In addition, a long-term mechanism may involve differential regulation of $\mathrm{Cl}^{-}$pumps at the level of gene expression. Injury may reverse the polarity of some $\mathrm{Cl}^{-}$transporters; an inward $\mathrm{Cl}^{-}$ transporter has been postulated in early development (Misgeld et al., 1986), and developing neurons show a reduced outward $\mathrm{Cl}^{-}$ transport (Luhmann and Prince, 1991). Traumatized neurons had a resting membrane potential that was depolarized by $12 \mathrm{mV}$ relative to age-matched controls. This difference in membrane potential may account for part of the depolarizing effect of GABA but is unlikely to account for all of it, because the difference between control and trauma groups in the GABA reversal potential was twice the magnitude, $25 \mathrm{mV}$, the difference in resting membrane potential.

Hypotonic conditions have been found to activate both $\mathrm{K}^{+}$ currents and $\mathrm{Cl}^{-}$currents in non-neuronal cells (Fatherazi et al., 1994; Hallows and Knauf, 1994). If neurons behave in parallel, then this could lead to a decreased intracellular $\mathrm{K}^{+}$and an increased intracellular $\mathrm{Cl}^{-}$concentration, resulting in a depolarized reversal potential for $\mathrm{GABA}$-evoked $\mathrm{Cl}^{-}$currents. In addition, injury may alter intracellular $\mathrm{HCO}_{3}^{-}$, an ion that can pass through the GABA-regulated anion channel (Kaila, 1994).

A recent paper reported that activity-dependent GABA excitation was dependent on $\mathrm{HCO}_{3}^{-}$, and no GABA-mediated excitation could be found in HEPES buffer (Staley et al., 1995). However, in that paper, the $\mathrm{Cl}^{-}$concentration was maintained at a constant level through the conventional whole-cell recording electrode, reducing the possibility of outward $\mathrm{Cl}^{-}$movement. In the present study, GABA-mediated excitation was detected in HEPES buffer with gramicidin-perforated whole-cell recording after injury. Under these conditions, a depolarizing role for $\mathrm{HCO}_{3}^{-}$would be unlikely.

Although changes in the expression in GABA receptor subtypes after trauma may be responsible for some physiological differences (Fritschy et al., 1994; Mathews et al., 1994), it seems unlikely that this could be responsible for GABA-mediated depolarizations. This is consistent with our previous data showing that the GABA-mediated single-channel conductance in developing hypothalamic neurons was not dramatically different than the conductance in mature neurons, although the GABA effect in the developing neurons was depolarizing (Chen et al., 1996). Could the loss of neurites during trauma lead to a loss of hyperpolarizing $\mathrm{Cl}^{-}$channels? To the contrary, several reports (Anderson et al., 1980; Alger and Nicoll, 1982) have suggested that focused application of GABA may depolarize dendrites of some cells, but hyperpolarizes their cell body. This suggests that our results probably are not simply attributable to the loss of hyperpolarizing $\mathrm{Cl}^{-}$channels on dendrites.

Our results suggest that after trauma, some neurons show a depolarizing response to GABA, as demonstrated by whole-cell gramicidin recording and nimodipine-sensitive $\mathrm{Ca}^{2+}$ rises evoked by GABA. In some situations, this depolarizing activity could lead to an increase in firing rate (Chen et al., 1996), but it also could serve to shunt currents evoked by excitatory transmitters such as glutamate. Whether GABA would increase or decrease activity would depend on the relative reversal potentials for GABA, the resting membrane potential, the threshold for spike generation, and the relative timing of GABA and glutamate stimulation.

The ability of GABA to raise $\mathrm{Ca}^{2+}$ after injury may allow it to modulate gene expression (Vaccarino et al., 1992; Bading et al., 1993), influence growth cone guidance (Mattson and Kater, 1987; Obrietan and van den Pol, 1996), and possibly reduce cell death from suboptimal cytosolic $\mathrm{Ca}^{2+}$ (Franklin and Johnson, 1992). GABA has been reported to enhance neuritic outgrowth and synaptic maturation in early development (Spoerri, 1988; Michler, 1990; Barbin et al., 1993) and may play a parallel role after injury. On the other hand, after trauma, GABA could raise $\mathrm{Ca}^{2+}$ above normal levels, potentially exacerbating secondary injury. The present results also indicate that neuronal communication that is dependent on normal GABA inhibitory mechanisms may be abnormal due to excitatory actions of GABA in traumatized circuits.

\section{REFERENCES}

Alger BE, Nicoll RA (1982) Feed-forward dendritic inhibition in rat hippocampal pyramidal cells studied in vitro. J Physiol (Lond) 328:105-123.

Anderson P, Dingledine R, Gjerstad L, Langmoen I, Laursen A (1980) Two different responses of hippocampal pyramidal cells to application of gamma-amino butyric acid. J Physiol (Lond) 305:279-296.

Bading H, Ginty D, Greenberg M (1993) Regulation of gene expression in hippocampal neurons by distinct calcium signaling pathways. Science 260:181-186.

Barbin G, Pollard H, Gaïarsa J, Ben-Ari Y (1993) Involvement of $\mathrm{GABA}_{\mathrm{A}}$ receptors in the outgrowth of cultured hippocampal neurons. Neurosci Lett 152:150-154.

Barres B (1991) New roles for glia. J Neurosci 11:3685-3694.

Ben-Ari Y, Cherubini E, Corradetti R, Gaiarsa J (1989) Giant synaptic potentials in immature rat CA3 hippocampal neurones. J Physiol (Lond) 416:303-325.

Chen C, Trombley PQ, van den Pol AN (1995) GABA receptors precede glutamate receptors in hypothalamic development; differential regulation by astrocytes. J Neurophysiol 1473-1484.

Chen C, Trombley PQ, van den Pol AN (1996) Excitatory action of GABA in developing hypothalamic neurons. J Physiol (Lond), in press.

Choi D (1988) Glutamate neurotoxicity and diseases of the nervous system. Neuron 1:623-634.

Cherubini E, Gaiarsa J, Ben-Ari Y (1991) GABA: an excitatory transmitter in early postnatal life. Trends Neurosci 14:515-519.

Connor J, Tseng H, Hockberger P (1987) Depolarization-and transmitter-induced changes in intracellular $\mathrm{Ca}^{2+}$ of rat cerebellar granule cells in explant cultures. J Neurosci 7:1384-1400.

Decavel C, van den Pol AN (1990) GABA: a dominant transmitter in the hypothalamus. J Comp Neurol 302:1019-1037.

Decavel C, van den Pol AN (1992) Converging GABA- and glutamateimmunoreactive axons make synaptic contact with identified hypothalamic neurosecretory neurons. J Comp Neurol 316:104-116.

Ebihara S, Shirato K, Harata N, Akaike N (1995) Gramicidin-perforated patch recording: GABA response in mammalian neurones with intact intracellular chloride. J Physiol (Lond) 484:77-86.

Fatherazi S, Izutsu KT, Wellner RB, Belton CM (1994) Hypotonically activated chloride current in HSG cells. J Membr Biol 142:181-193.

Fiszman M, Novotny E, Lange G, Barker J (1990) Embryonic and early postnatal hippocampal cells respond to nanomolar concentrations of muscimol. Dev Brain Res 53:186-193.

Franklin J, Johnson E (1992) Suppression of programmed neuronal death by sustained elevations of cytoplasmic calcium. Trends Neurosci 15:501-508.

Fritschy JM, Paysan J, Enna A, Mohler H (1994) Switch in expression of rat $\mathrm{GABA}_{\mathrm{A}}$-receptor subtypes during postnatal development: an immunohistochemical study. J Neurosci 14:5302-5324.

Grynkiewicz G, Poenie M, Tsien R (1985) A new generation of calcium indicators with greatly improved fluorescence properties. J Biol Chem 260:3440-3450.

Hallows KR, Knauf PA (1994) Regulatory volume decrease in HL-60 cells: importance of rapid changes in permeability of $\mathrm{Cl}^{-}$and organic solutes. Am J Physiol 267:C1045-C1056. 
Kaila K (1994) Ionic basis of $\mathrm{GABA}_{\mathrm{A}}$ receptor channel function in the nervous system [review]. Prog Neurobiol 42:489-537.

Kim YI, Dudek FE (1992) Intracellular electrophysiological study of suprachiasmatic nucleus neurones in rodents: inhibitory synaptic mechanisms. J Physiol (Lond) 458:247-260.

Luhmann H, Prince D (1991) Postnatal maturation of the GABAergic system in rat neocortex. J Neurophysiol 65:247-263.

Mathews C, Bolos-Sy AM, Holland KD, Isenberg KE, Covey DF, Ferrendelli JA, SM Rothman (1994) Developmental alteration in GABA receptor structure and physiological properties in cultured cerebellar granule neurons. Neuron 13:149-158.

Mattson MP, Kater SB (1987) Calcium regulation of neurite elongation and growth cone motility. J Neurosci 7:4034-4043.

Mattson MP, Kater SB (1989) Excitatory and inhibitory neurotransmitters in the generation and degeneration of hippocampal neuroarchitecture. Brain Res 478:337-348.

McCarthy RT, TanPiengco PE (1992) Multiple types of high-threshold calcium channels in rabbit sensory neurons: high-affinity block of neuronal L-type by nimodipine. J Neurosci 12:2225-2234.

Michler A (1990) Involvement of GABA receptors in the regulation of neurite growth in cultured embryonic chick tectum. Int J Dev Neurosci 8:463-472.

Misgeld U, Deisz R, Dodt H, Lux H (1986) The role of chloride transport in postsynaptic inhibition of hippocampal neurons. Science 232:1413-1415.

Myers VB, Haydon DA (1972) Ion transfer across lipid membranes in the presence of gramicidin A. II. The ion selectivity. Biochim Biophys Acta 274:313-322.

Nowycky MC, Fox AP, Tsien RW (1985) Three types of neuronal calcium channel with different calcium agonist sensitivity. Nature 316:440-443.

Obata K, Oide M, Tanaka H (1978) Excitatory and inhibitory actions of GABA and glycine on embryonic chick spinal neurons in culture. Brain Res 144:179-184.

Obrietan K, van den Pol AN (1995a) GABA neurotransmission in the hypothalamus: developmental reversal from $\mathrm{Ca}^{2+}$ elevating to depressing. J Neurosci 15:5065-5077.

Obrietan K, van den Pol AN (1995b) Calcium hyperexcitability in neurons cultured with glutamate receptor blockade. J Neurophysiol $73: 1524-1536$.

Obrietan K, van den Pol AN (1996) Growth cone calcium rise evoked by GABA. J Comp Neurol, in press.
Olney J, Sharpe L (1969) Brain lesions in an infant rhesus monkey treated with monosodium glutamate. Science 166:386-388.

Randle J, Bourque C, Renaud L (1986) Characterization of spontaneous and evoked postsynaptic potentials in rat supraoptic neurosecretory neurons in vitro. J Neurophysiol 56:1703-1717.

Reichling DB, Kyeozis A, Wang J, McDermott AB (1994) Mechanisms of GABA and glycine depolarization-induced calcium transients in rat dorsal horn neurons. J Physiol (Lond) 476:411-421.

Reuter H (1995) Measurements of exocytosis from single presynaptic nerve terminals reveal heterogeneous inhibition by $\mathrm{Ca}^{2+}$-channel blockers. Neuron 14:773-779.

Spoerri P (1988) Neurotrophic effects of GABA in cultures of embryonic chick brain and retina. Synapse 2:11-22.

Staley KJ, Soldo BL, Proctor WR (1995) Ionic mechanisms of neuronal excitation by inhibitory GABAA receptors. Science 269:977-981.

Tappaz M, Oertel W, Wassef M, Mugnaini E (1982) Central GABAergic neuroendocrine regulation: pharmacological and morphological evidence. Prog Brain Res 55:77-96.

Thayer SA, Murphy SN, Miller RJ (1986) Widespread distribution of dihydropyridine-sensitive calcium channels in the central nervous system. Molecular Pharmacol 30:505-509.

Vaccarino F, Haywark M, Nestler E, Duman R, Tallman J (1992) Differential induction of immediate early genes by excitatory amino acid receptor types in primary cultures of cortical and striatal neurons. Mol Brain Res 12:233-241.

van den Pol AN (1985) Dual ultrastructural localization of two neurotransmitter-related antigens: colloidal gold labeled neurophysin immunoreactive supraoptic neurons receive peroxidase labeled glutamate decarboxylase or gold labeled GABA immunoreactive synapses. J Neurosci 5:2940-2954.

van den Pol AN, Trombley PQ (1993) Glutamate neurons in hypothalamus regulate excitatory transmission. J Neurosci 13:2829-2836.

van den Pol AN, Obrietan K, Cao V, Trombley PQ (1995) Embryonic hypothalamic expression of functional glutamate receptors. Neuroscience 67:419-439.

Walton MK, Schaffner AE, Barker JL (1993) Sodium channels, GABA receptors, and glutamate receptors develop sequentially on embryonic rat spinal cord cells. J Neurosci 13:2068-2084.

Yuste R, Katz L (1991) Control of postsynaptic $\mathrm{Ca}^{2+}$ influx in developing neocortex by excitatory and inhibitory neurotransmitters. Neuron 6:333-344. 